Journal of Mathematics and Statistics 7 (3): 198-206, 2011

ISSN 1549-3644

(C) 2011 Science Publications

\title{
Microwave Assisted Bioethanol Production from Sago Starch by Co-Culturing of Ragi Tapai and Saccharomyces Cerevisiae
}

\author{
N. Saifuddin and Refal Hussain \\ Department of Engineering Science and Mathematics, College of Engineering, \\ University Tenaga Nasional, Jalan IKRAM-UNITEN 43000, Kajang, Selangor, Malaysia
}

\begin{abstract}
Problem statement: Environmental issues such as global warming and recent events throughout the world, including the shortage of petroleum crude oil, the sharp increase in the cost of oil and the political instability of some crude oil producing countries, have demonstrated the vulnerability of the present sources for liquid fuel. These situations have created great demand for ethanol from fermentation process as green fuel. A main challenge in producing the ethanol is the production cost. A rapid and economical single step fermentation process for reliable production of bioethanol was studied by co-culturing commercialized ragi tapai with Saccharomyces cerevisae using raw sago starch. Approach: Enzymatic hydrolysis of sago starch by various amylolytic enzymes was investigated to reveal the potential coupling mechanism of Microwave Irradiation-Enzyme Coupling Catalysis (MIECC). Results: It was shown that enzymatic hydrolysis of starch using typical enzymes may successfully be carried out at microwave condition. The MIECC resulted in increasing initial reaction rate by about 2 times. The results testify on specific activation of enzymes by microwaves and prove the existence of non-thermal effect in microwave assisted reactions. Low power microwave irradiation $(80 \mathrm{~W})$ does not increase the temperature beyond $40^{\circ} \mathrm{C}$ and hence denaturation of the enzyme is avoided. The maximum ethanol fermentation efficiency was achieved $(97.7 \%$ of the theoretical value) using $100 \mathrm{~g} \mathrm{~L}^{-1}$ sago starch concentration. The microwave assisted process improved the yield of ethanol by $45.5 \%$ compared to the non-microwave process. Among the other advantages of co-culturing of ragi tapai with $S$. cerevisiae is the enhancement of ethanol production and prevention of the inhibitory effect of reducing sugars on amylolytic activity and the reaction could be completed within $32 \pm 1$ h. Conclusion: The present study have demonstrated the ability of using cheaply and readily ragi tapai for conversion of starch to glucose and the utilization of sago starch as a feed stock, which is cheaper than other starches like corn and potato. The present study has highlighted the importance of well controlled microwave assisted enzymatic reaction to enhance the overall reaction rate of the process.
\end{abstract}

Key words: Sago starch, bioethanol, co-culture, enzymatic hydrolysis, Saccharomyces cerevisiae, microwave assisted reaction, non-thermal effects, enzyme denaturation, Simultaneous Saccharification and Fermentation (SSF)

\section{INTRODUCTION}

Heavy reliance on the use of fossil resources for the generation of transportation fuels and materials, has cause a rising concern over their cost, sustained availability and impact on global warming and pollution. Motor vehicles account for a significant portion of urban air pollution in much of the developing world. It is projected that there will be 1.3 billion light duty vehicles, automobiles, light trucks, SUVs and minivans, on roadways around the world by 2030 (Balat and Balat, 2009). According to Goldemberg
(2008), motor vehicles account for more than $70 \%$ of global carbon monoxide (CO) emissions and $19 \%$ of global carbon dioxide $\left(\mathrm{CO}_{2}\right)$ emissions. $\mathrm{CO}_{2}$ emissions from a gallon of gasoline are about $8 \mathrm{~kg}$. Bio-fuels are liquid or gaseous fuels made from plant matter and residues, such as agricultural crops, municipal wastes and agricultural and forestry by-products. Liquid biofuels can be used as an alternative fuel for transport, besides other alternatives such as Liquid Natural Gas (LNG), Compressed Natural Gas (CNG), Liquefied Petroleum Gas (LPG) and hydrogen (Semin et al., 2009). Bioethanol produced from renewable biomass,

Corresponding Author: N. Saifuddin, Department of Engineering Science and Mathematics, College of Engineering, University Tenaga Nasional, Jalan IKRAM-UNITEN 43000, Kajang, Selangor, Malaysia 


\section{J. Math. \& Stat., 7 (3): 198-206, 2011}

such as sugar, starch, or lignocellulosic materials, is one of the alternative energy resources that are both renewable and environmentally friendly (Balat et al., 2008; Baras et al., 2002). It can be blended with petrol (E5, E10, E85) or used as neat alcohol in dedicated engines, taking advantage of the higher octane number and higher heat of vaporisation and it is also an excellent fuel for future advanced flexi-fuel hybrid vehicles (Chum and Overend, 2001; Kim and Dale, 2005). Internal combustion engines operating on ethanol also produce fewer greenhouse gas (GHG) emissions since ethanol is less carbon-rich than gasoline.

Fermentation-derived ethanol can be produced from sugar, starch or lignocellulosic biomass. Sugar and starch-based feedstocks are currently predominant at the industrial level and they are so far economically favorable. Starch-based materials are currently most utilized for the ethanol production in North America and Europe. The hydrolysis of starch may be considered as a key step in the processing of starchbased feedstock for the bioethanol production. The main role of this step is to effectively provide the conversion of two major starch polymer components: amylose, a mostly linear $\alpha$-D-(1-4)-glucan and branched amylopectin to fermentable sugars that could subsequently be converted to ethanol by yeasts or bacteria. The most commonly used distillers yeast $S$. cerevisiae is unable to hydrolyse starch. Traditional production of ethanol from starch requires a three-stage process; liquefaction of starch by $\alpha$-amylase, saccharification of liquefied starch by enzymes to sugars followed by fermentation using $S$. cerevisiae. Amylolytic enzymes from bacteria and fungi are used for the saccharification of starch and this adds to the overall cost of the bioethanol production process. Simultaneous saccharification of starch with an amylolytic yeast or mold and fermentation of saccharified starch by distillers yeast is an effective method for direct fermentation of starch (Somda et al., 2011; Nadir et al., 2009).

Sago palm Metroxylon sagu is an important economic species and is now grown commercially in Malaysia, Indonesia, the Philippines and New Guinea for the production of sago starch. Sago Palm has a great potential to be a Malaysian leading producer of starch. From less than 20,000 hectares in 1991, sago plantations in Malaysia, have grown to around 53,000 hectares in 2010. One of the potential uses of the sago palm is for the production of bioethanol. More importantly, the sago starch is of such a quality that ethanol conversion efficiencies of up to $72 \%$ can be obtained (for hydrated ethanol). Taking an optimistic yield of 20 tons of clean starch per hectare, this comes down to an alcohol yield of 14,400 liters, (1540 gallons) per acre, making sago one of the most productive energy crops.

Current world bioethanol research is driven by the need to reduce the costs of production. For example, improvement in feedstock pretreatment, shortening of fermentation time, lowering the enzyme dosages, improving the overall starch hydrolysis and integration of the Simultaneous Saccharification and Fermentation (SSF) process could be the basis of cutting down production costs. Many microorganisms including Saccharomyces cerevesiae (yeast) are not able to produce ethanol from starch due to lack of starchdecomposing enzyme. Specific enzymes such as amylase, amyloglucoamylase and pulluanase are needed for hydrolyzing starch (Nurachman et al., 2010; Jamai et al., 2007). Tapai is a traditional fermented food popular in Malaysia and Indonesia. To prepare tapai, a carbohydrate source and an inoculum containing the microorganisms is necessary. The inoculum is called ragi tapai and is cheaply available in local market. Microorganisms found in the traditional ragi tapai are moulds (Rhizopus oryzae, Amylomyces rouxii, Mucor sp. and Candida utilis) and yeasts (Saccharomyces cerevisiae, Saccharomycopsis fibuliger, Endomycopsis burtonii). The moulds are strong amylolytic (Gandjar, 2003). Microwave Irradiation-Enzyme Coupling Catalysis (MIECC) has also been proven as a useful tool for many enzymatic transformations in both aqueous and organic solutions (Leadbeater et al., 2007; Yadav and Sajgure, 2007; Roy and Gupta, 2003). It has been proposed that in case of low power of high-frequency electromagnetic field the nonthermal activation of enzyme may be observed (Yadav and Lathi, 2007; Saifuddin et al., 2009). Enzymatic hydrolysis of starch is a very important not only for bioethanol production but many other industrial process and study of amylolytic enzyme working at microwave conditions is of great importance from both the scientific and industrial interest.

The objective of this study is to improve the bioethanol production from raw sago starch by using co-culturing approach and microwave irradiation. Microwave pretreatment will be carried on the starch solution as some previous studies have shown that application of microwave irradiation pretreatment may significantly increase the conversion of starch materials to glucose (Zhu et al., 2006; Palav and Seetharaman, 2007). The bioconversion of the microwave treated sago starch in single step process will be performed by co-culturing of commercial ragi tapai and Saccharomyces cerevisiae. 


\section{MATERIALS AND METHODS}

Microorganisms, culture conditions and reagents: Saccharomyces Cerevisiae ("Angel" Super dry Yeast for fuel ethanol) was purchased from Angel Yeast Co., Ltd. China. Bacto-Peptone and Yeast extract was purchased from BD Diagnostic Systems USA. The other culture used was commercial ragi tapai (which provides the amylolytic enzymes). It was obtained from the local market.

Sago based on starch flour used in this experiment is from one brand and was obtained from local market in Malaysia. Saccharomyces cerevisiae was used for the fermentation of hydrolyzed sago starch. Before using as inoculums, both, the dry $S$. Cerevisiae $(5 \mathrm{~g})$ and ragi tapai $(10 \mathrm{~g})$ were aerobically propagated separately in $250 \mathrm{~mL}$ flasks containing $100 \mathrm{~mL}$ YEP broth media (10 $\mathrm{g} \mathrm{L}^{-1}$ yeast extract, $10 \mathrm{~g} \mathrm{~L}^{-1}$ Peptone and $5 \mathrm{~g} \mathrm{~L}^{-1} \mathrm{NaCl}$ ) at $37^{\circ} \mathrm{C}$ and $250 \mathrm{rpm}$ for $3 \mathrm{~h}$. The liquid media was autoclaved at $121^{\circ} \mathrm{C}$ for $15 \mathrm{~min}$ before the aerobic propagation.

The chemical reagents were of analytical grade and used without further purification. Sodium hydroxide was purchased from Merck; acetic acid, sulfuric acid, calcium chloride, ammonium sulphate, magnesium sulphate, anhydrous ethanol, calcium hydroxide and anhydrous glucose were purchased from J.T. Baker.

Optimizing microwave irradiation duration and sago starch concentration: In a typical experiment 25 $\mathrm{g}$ of sago starch and $1 \mathrm{mg}$ of $\mathrm{CaCl}_{2}$ were dispersed in $250 \mathrm{~mL}$ of deionized water placed in glass flasks $(10 \%$ w/v sago starch slurry). The $\mathrm{pH}$ was adjusted to 7.2. The mixture was heated up to $60^{\circ} \mathrm{C}$ for 5 min to obtain starch slurry. The slurry was heated to $80^{\circ} \mathrm{C}$ for $45 \mathrm{~min}$ to reduce viscosity. The slurry was allowed to cool to $40^{\circ} \mathrm{C}$ before addition of the $10 \mathrm{~mL}$ of $10 \%$ ragi tapai culture suspension. The mixture was then subjected to the microwave treatment in a microwave oven (Sanyo, EM-S9515W). Output power was set at $80 \mathrm{~W}$ and the effects of heating between 1-10 min were investigated. The control samples were not subjected to the microwave irradiation. After the microwave treatment at each time interval, the flasks were kept in a water bath with shaker at $45^{\circ} \mathrm{C}$ with agitation at $60 \mathrm{rpm}$ for up to $20 \mathrm{~min}$. At the end of $20 \mathrm{~min}$, the amount of glucose released was determined for each flask. The result will indicate the optimal time of microwave exposure to achieve the highest amount of glucose.

For optimization of sago starch concentration, similar experiment was conducted but using sago starch slurry of 20\% (50 g/250 mL deionized water) and 30\% (75 g/250 mL deionized water). The microwave output power was set at $80 \mathrm{~W}$ and the exposure time was set at 5 min (optimal time). The amount of glucose was measured as mentioned previously after $20 \mathrm{~min}$ incubation at $45^{\circ} \mathrm{C}$ with agitation at $60 \mathrm{rpm}$. The result will indicate the optimal concentration of starch slurry to achieve highest amount of glucose and the highest percentage conversion to glucose. Percentage conversion to glucose was calculated using the following equation. The theoretical amount of glucose produced is $1110 \mathrm{~g}$ glucose for $1 \mathrm{~kg}$ starch $(100 \%$ efficiency):

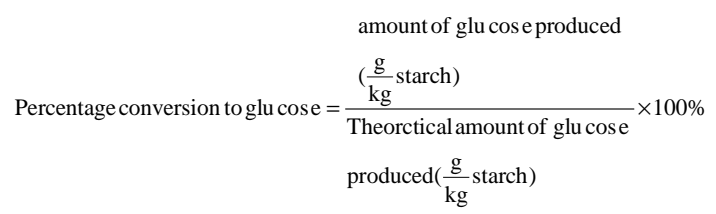

For optimization of level of ragi tapai concentration, another similar experiment was conducted using fix concentration of sago starch slurry at $10 \%(25 \mathrm{~g} / 250 \mathrm{~mL}$ deionized water) and three levels of the ragi tapai concentration of $10 \%, 20 \%$ and $30 \%$. The microwave output power was set at $80 \mathrm{~W}$ and the exposure time was set at 5 min (optimal time). The amount of glucose was measured as mentioned previously after $20 \mathrm{~min}$ incubation at $45^{\circ} \mathrm{C}$ with agitation at $60 \mathrm{rpm}$. The result will indicate the optimal concentration of ragi tapai to achieve highest the highest percentage conversion to glucose. Percentage conversion to glucose was calculated using the previously described equation.

Microwave assisted simultaneous saccharification and fermentation of sago starch: The hydrolysis of sago starch followed by yeast fermentation in single step was performed by sequential co-culture process. The yeast (S. cerevisiae) was added 2 hours after the microwave assisted saccharification process for the initiation of the fermentation process. The starch slurry was prepared as mentioned above. The sago starch slurry after addition of $10 \mathrm{~mL}$ of $10 \%$ ragi tapai was subjected to microwave treatment at $80 \mathrm{~W}$ for $5 \mathrm{~min}$ (optimal time). After the microwave treatment, the flasks were kept in a water bath with shaker at $45^{\circ} \mathrm{C}$ with agitation at $60 \mathrm{rpm}$ for $2 \mathrm{~h}$, to facilitate enzymatic hydrolysis (saccharification) of starch to sugar (glucose). At the end of each saccharification period, the flask were individually fermented by addition of 10 $\mathrm{mL}$ of $5 \%$ S. Cerevisiae culture suspension (having an absorbance of $3.8-4.0$ at $450 \mathrm{~nm}$ ) along with $\left(\mathrm{NH}_{4}\right)_{2} \mathrm{SO}_{4}\left(1.3 \mathrm{~g} \mathrm{~L}^{-1}\right), \mathrm{MgSO}_{4} .7 \mathrm{H}_{2} \mathrm{O}\left(0.01 \mathrm{~g} \mathrm{~L}^{-1}\right)$ and $\mathrm{CaCl}_{2}\left(0.06 \mathrm{~g} \mathrm{~L}^{-1}\right)$.The $\mathrm{pH}$ was adjusted to 5.5. The 


\section{J. Math. \& Stat., 7 (3): 198-206, 2011}

mixture was then subjected to the microwave treatment in a microwave oven with output power $80 \mathrm{~W}$ for 5 min. After the microwave treatment, the glass flasks were kept in an incubated shaker at $100 \mathrm{rpm}$ and $37^{\circ} \mathrm{C}$ for $30 \mathrm{~h}$. Ethanol concentration was measured after the $30 \mathrm{~h}$ fermentation period.

Conventional saccharification and fermentation was also performed according to the method mentioned previously but without the use of microwave irradiation. This served as the control process.

Analytical methods: The ethanol and glucose concentration in the samples was measured at several intervals. Samples were collected at every $2 \mathrm{~h}$ interval for the first $12 \mathrm{~h}$ which consist of 6 data and another 10 data at every $6 \mathrm{~h}$ for the next $60 \mathrm{~h}$. A total of 16 data were collected for the entire run of $72 \mathrm{~h}$. During the sago starch hydrolysis and fermentation, the content of reducing sugars, calculated as glucose, was determined by 3,5-dinitrosalicylic acid (DNS) method (Miller, 1959). A standard curve was drawn by measuring the absorbance of known concentrations of glucose solutions at $570 \mathrm{~nm}$.

The ethanol concentrations of samples were determined using a spectrophotometric method with potassium dichromate reagent (Caputi et al., 1968). The supernatant taken at various interval was added with 25 $\mathrm{mL}$ of chromic acid (potassium dichromate reagent) followed by incubation at $80^{\circ} \mathrm{C}$ for $15 \mathrm{~min}$. After incubation $1 \mathrm{~mL}$ of $40 \%$ sodium potassium tartarate was added. The absorbance was measured in a UV-Vis spectrophotometer (spectronic 20) at $600 \mathrm{~nm}$. A standard graph was plotted by taking different concentration of absolute ethanol (10-100\%) and measuring its absorbance at $600 \mathrm{~nm}$. The concentration of ethanol from the various intervals was determined by reading off from the standard graph.

The fermentation efficiency was computed from the theoretical ethanol yield and that obtained in the various treatments using the equation:

$$
\begin{aligned}
& \text { Ethanol produced } \\
& \text { fermentation efficiency }=\frac{\left(\frac{\mathrm{g}}{\mathrm{kg}} \mathrm{starch}\right)}{\text { theorctical yeild }} \times 100 \% \\
& \text { of thanol }\left(\frac{\mathrm{g}}{\mathrm{kg}} \mathrm{starch}\right)
\end{aligned}
$$

Theoretical yield of ethanol is $567 \mathrm{~g} \mathrm{~kg}^{-1}$ starch and was calculated using the equation:

Theoreticalyield $\left(\mathrm{g} \mathrm{kg}^{-1}\right.$ starch $)=\frac{51^{\mathrm{a}} \times 1.11^{\mathrm{b}}}{1.0}$
Where:

$\mathrm{a}=$ Theoretical yield $(\mathrm{g})$ of ethanol from $1.0 \mathrm{~kg}$ glucose

$\mathrm{b}=$ Yield of glucose $(\mathrm{kg})$ from $1.0 \mathrm{~kg}$ starch

\section{RESULTS AND DISCUSSION}

Optimization of Microwave treatment for hydrolysis of starch: Hydrolysis of starch prior to fermentation to ethanol is a very important step because the yeast, $S$. cerevisiae, is non-amylolytic and was reported to be unable to hydrolyze starch (Jamai et al., 2007). It is however, a very good candidate for fermentation of sugar to ethanol. Figure 1 presents the influence of the duration of the microwave treatment $(80 \mathrm{~W})$ on the concentration of glucose achieved after the liquefaction of the sago starch slurry. The low level of MW power was used in order to avoid the enzyme denaturation and to minimize the thermal effects of the process. As shown in Fig. 1, the duration of 5 min was the optimal exposure time for the microwave treatment at $80 \mathrm{~W}$ output power. Therefore microwave treatment of $5 \mathrm{~min}$ was selected for further experiments since during that time maximal glucose concentrations were attained. The microwave experiments were carried out at low power level and constant temperature. The reason is the well known phenomenon of enzyme denaturation at high temperature which decreases the catalytic activity of the enzymes. Microwave treatment helps in destroying the crystalline starch structure and hence makes it easier for the enzymes to convert it to glucose. Similarly, relatively short duration of the microwave treatment was also selected by other investigator as appropriate for destroying the starch crystalline arrangement (Palav and Seetharaman, 2007). Khanal et al. (2007) reported that ultrasound pretreatment $(2 \mathrm{kHz}$; 20 and $40 \mathrm{~s}$ ) enhanced glucose yield due to reduction in particle size and better mixing. It may also help in the release of starch from its complex with lipids. However, Nikolic et al. (2010) found that ultrasound treatment consumed a large amount of energy, adding further towards the cost of bioethanol production. On the other hand, similar increased in efficiency of the hydrolysis process probably through the same phenomenon can be obtained by using microwave irradiation which consumes much lesser energy than ultrasound.

The results from starch concentration optimization experiments $(10,20$ and $30 \%)$ indicated that as the starch slurry concentration increased, the amount of conversion of starch to glucose also increased. Even though the quantity of glucose released was more from $30 \%$ (w/v) slurry (Fig. 2), the percentage conversion to glucose was the highest with $10 \%$ (w/v) slurry (Fig. 3). 


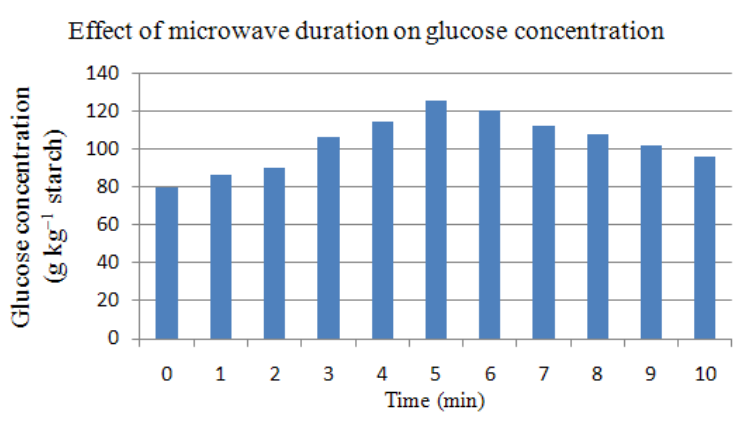

Fig. 1: The effect of time of microwave exposure on glucose concentration obtained after hydrolysis of sago starch (10\%) at $80 \mathrm{~W}$ with $10 \mathrm{~mL}$ of $10 \%$ ragi tapai. The control sample is the $0 \mathrm{~min}$

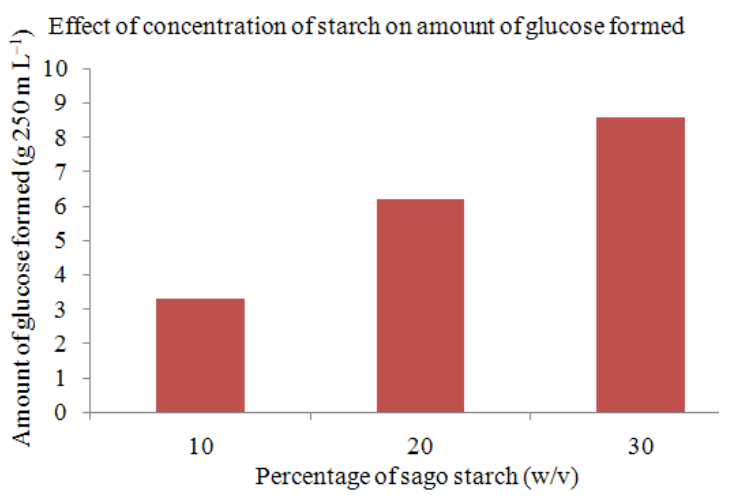

Fig. 2: All the three starch slurries (10, 20 and 30\%) were added initially added with $10 \mathrm{~mL}$ of $10 \%$ ragi tapai and irradiated with microwave at $80 \mathrm{~W}$ for $5 \mathrm{~min}$. The amount of glucose released was monitored after $20 \mathrm{~min}$ incubation at $45^{\circ} \mathrm{C}$

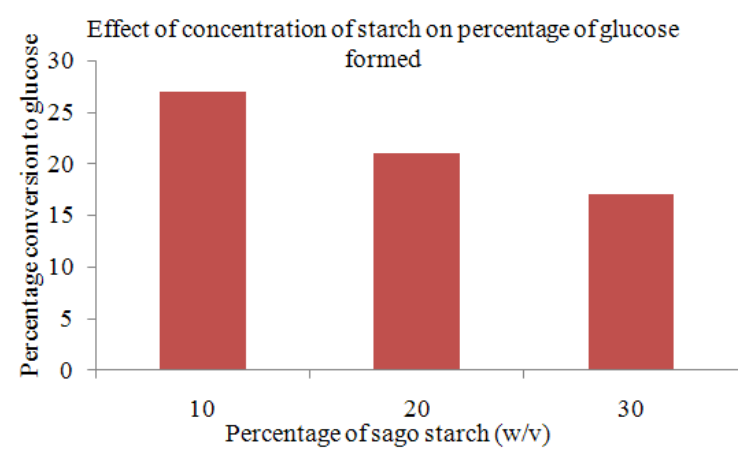

Fig. 3: The percentage conversion to glucose after 20 min incubation at $45^{\circ} \mathrm{C}$ for three different concentrations of starch slurry (10, 20 and 30\%) was calculated from the data obtained from Fig. 2 using the equation given in the text

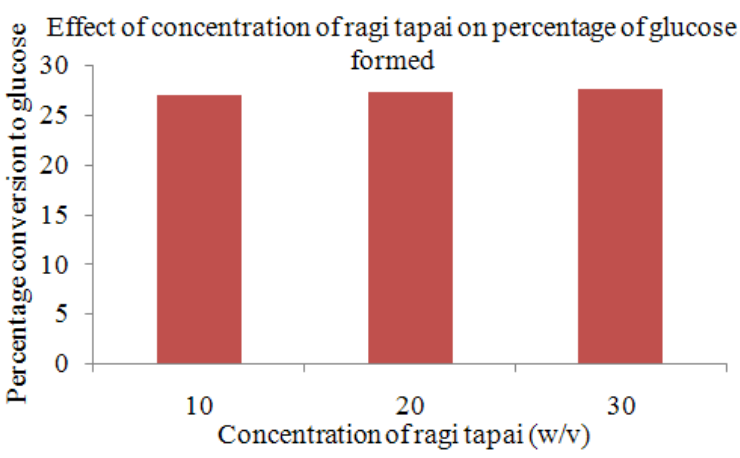

Fig. 4: The percentage conversion to glucose after 20 min incubation at $45^{\circ} \mathrm{C}$ for three different concentrations of ragi tapai $(10,20$ and $30 \%)$ at starch slurry concentration of $10 \%$ was calculated using the equation given in the text

When $20 \%(\mathrm{w} / \mathrm{v})$ and $30 \%(\mathrm{w} / \mathrm{v})$ starch slurry were used the rate of conversion to glucose did not increase proportionally with the increase in starch content. In fact the rate was fastest with $10 \%$ slurry. In high viscous environment i.e. higher starch concentration the inactivation of amylase and other enzymes during the microwave irradiation may be observed because of hot spots generated in the system arising from poor heat exchange. On the other hand at lower viscosity i.e. lower starch concentrations heat exchange is better and hot spots are not created. It is anticipated that at low power level of microwave irradiation non-thermal effects of microwave play a role. At low power level the active site of the enzyme molecules may undergo conformational changes to favor the cleavage of the glycosidic bonds. This will enhance the efficiency of the enzyme. Non-thermal effects or microwave effect has been observed in a number of microwave assisted catalytic or enzymatic reactions (La Hoz et al., 2007; Yadav and Lathi, 2007; Saifuddin et al., 2011). Previous study on ethanol production from fresh cassava mash also showed that high viscosity caused resistance to solid-liquid separation and lower fermentation efficiency (Srikanta et al., 1992). High viscosity also causes several handling difficulties during processes and may lead to incomplete hydrolysis of starch to fermentable sugar (Wang et al., 2008).

There was minimal increase in the percentage conversion of starch, when the ragi tapai concentration levels were increased from 10-20 and 30\% with the starch slurry at $10 \%$ (Fig. 4). Increasing the level of concentration of ragi tapai did not result in any further increase in the starch hydrolysis. Most studies have shown that $S$. cerevisiae is non-amylolytic yeast and 
was reported to be unable to hydrolyze starch (Jamai et al., 2007). However study by Azmi et al. (2010) has shown that $S$. cerevisiae has the ability of hydrolysing starch but at very low rate. The study also reported that ragi tapai is more efficient in hydrolyzing raw starch to glucose compared to the fungi Candida tropicalis (Azmi et al., 2010). This will subsequently produce higher ethanol.

Microwave assisted simultaneous saccharification and fermentation of sago starch: Microwave assisted fermentation by yeast was performed by sequential coculture process in a single step. The $S$. cerevisiae (yeast) was added $2 \mathrm{~h}$ after the microwave assisted saccharification treatment. This was done in order to bring sufficient amount of sugar before the start of fermentation. Two sets of experiments (microwave assisted saccharification and fermentation and conventional saccharification and fermentation) were performed. In microwave assisted sacchrification and fermentation samples were subjected to $80 \mathrm{~W}$ microwave irradiation for $5 \mathrm{~min}$ after addition of ragi tapai. After saccharification period of $2 \mathrm{~h}$ at $45^{\circ} \mathrm{C}$ the fermentation process was started by adding the yeast and subjected to microwave irradiation at $80 \mathrm{~W}$ for 5 min. After which it was incubated at $37^{\circ} \mathrm{C}$ for up to 36 h. Figure 5 shows the result of both the microwave assisted saccharification and fermentation and conventional saccharification and fermentation. The microwave assisted process showed higher amount of ethanol production with $553 \mathrm{~g}$ ethanol per $\mathrm{kg}$ starch produced after $30 \mathrm{~h}$ of fermentation. In the conventional process the amount of ethanol produced was $296.1 \mathrm{~g}$ per $\mathrm{kg}$ starch at $30 \mathrm{~h}$ of fermentation. The co-culture after $2 \mathrm{~h}$ allows the mixed culture to hydrolyze the raw starch into glucose and made them available for $S$. cerevisiae to subsequently ferment them into ethanol. Simultaneous saccharification and fermentation has the advantage that high sugar concentrations are never achieved in the system, which will facilitate the enzymatic hydrolysis of starch to be carried in the forward direction. Microwave aided ragi tapai hydrolysis followed by yeast fermentation for $36 \mathrm{~h}$ showed that the residual reducing sugar in the fermented broth after $30 \mathrm{~h}$ was about $2.25 \pm 1.50 \mathrm{~g} \mathrm{~L}^{-1}$. Hence the total amount of utilized glucose was $98 \%$ indicating the end of fermentation. This indicated that most of the sugars formed were simultaneously fermented to ethanol before it accumulate and correspondingly inhibit the fermentation process by osmotic pressure on the cells (Bai et al., 2008). For the non-microwave process residual reducing sugars in the fermented broth after $30 \mathrm{~h}$ was about $10.60 \pm 1.50 \mathrm{~g} \mathrm{~L}^{-1}$.

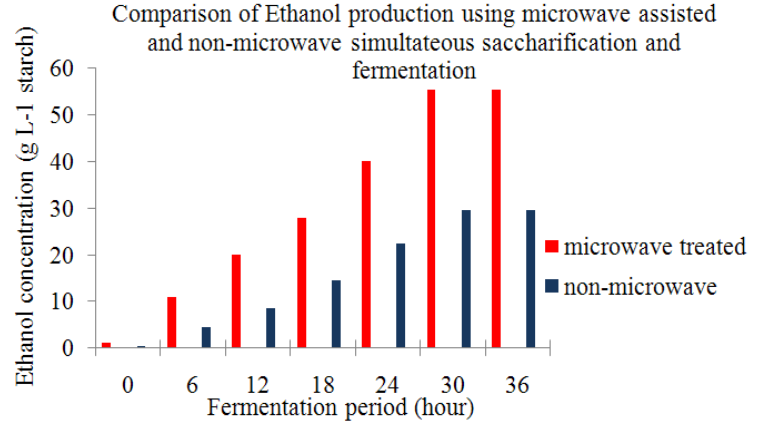

Fig. 5: The starch slurry concentration used was $100 \mathrm{~g}$ $\mathrm{L}^{-1}$. Both saccharification and fermentation were subjected to $80 \mathrm{~W}$ microwave irradiation for 5 min. For non-microwave saccharification and fermentation microwave irradiation was not applied

Fermentation efficiency for microwave added saccharification and fermentation was very high with $97.7 \%$ efficiency. The non-microwave process had fermentation efficiency of about $52.2 \%$. Previous study on enzyme catalysed liquefaction and saccharification of sweet potato starch showed that liquezyme X (Novo Industries, Denmark) could liquefy the starch at $\mathrm{pH} 7.0$ and $90^{\circ} \mathrm{C}$ within $1 \mathrm{~h}$, followed by saccharification by Dextrozyme GA at $\mathrm{pH} 4.0$ and $60^{\circ} \mathrm{C}$. However, approximately $95-96 \%$ conversion of starch only could be achieved during a saccharification period of $48 \mathrm{~h}$.

When we compared the results obtained in the simultaneous saccharification and fermentation of corn meal with microwave (Nikolic et al., 2008) and ultrasound pretreatment (Nikolic et al., 2010) to the control sample, the ethanol concentration was increased by $13.4 \%$ by microwave and $11.15 \%$ by ultrasound pretreatment. It was mentioned that this may be due to the mechanism of microwave action on swelling and gelatinisation of starch granules and destruction of the starch crystalline arrangement was probably different compared to the ultrasound. However in this study the improvement recorded with microwave treatment for both the processes (saccharification and fermentation) gave a total efficiency improvement of about $45.5 \%$. As stated earlier low power microwave irradiation does not increase the temperature beyond $40^{\circ} \mathrm{C}$ and hence denaturation of the enzyme is avoided. The significant contributor is proposed to be the non-thermal effects, while the thermal effect plays only a minor role under these conditions. The "thermal" effects refer to interactions resulting in increased random motion of particles (e.g., atoms, molecules, ions, or electrons) 


\section{J. Math. \& Stat., 7 (3): 198-206, 2011}

where the kinetic energy statistics of such fluctuations are represented by a single thermodynamic equilibrium distribution (i.e., Maxwell-Boltzmann, Bose-Einstein, or Fermi-Dirac). "Non-thermal" effects refer to interactions resulting in non-equilibrium energy fluctuation distributions or deterministic, time-averaged drift motion of matter (or both) (Kuhnert, 2002; Booske et al., 1997). This provides the molecule collision under microwave irradiation extra driving force compared to that under conventional heating, which results in higher rate of reaction under mmicrowave irradiation as long as the enzyme is not deactivated by microwave. The other contribution of the non-thermal effects is that microwave energy can also modulate the configuration of enzyme molecules by accelerating the molecular rotation and electron spin oscillation of the active site of the enzyme, which can provide more chance to make the substrates fit to the enzyme in unit of time (Saifuddin et al., 2011). The specific nature of this enzyme increases yield tremendously. $\mathrm{Li}$ and Yang (2008) in the production of zeolite membranes, have speculated on the non-thermal effects of microwave reaction. Apparently, microwave heating could result in different membrane morphology, orientation, composition for the zeolite membranes. Huang et al. (2005) reported that there is microwave effect on substrate specificity of alcohol. The reaction rate altering can be explained in respect of two important parameters-polarity and steric hindrance effects.

\section{CONCLUSION}

Ragi tapai was chosen based on its ability to produce glucose and ethanol yields from starch directly as presented previous by other researches, but with low yields (Azmi et al., 2010). Since the yields are low, coculturing with yeast had been proposed as a way to increase the yield. Maximum processing time needed was $2 \mathrm{hr}$ of hydrolysis and 30 hours of fermentation for the ragi tapai-yeast system. Rapid utilization of the glucose by yeast also prevented bacterial contamination in the broth, permitting an almost complete conversion of glucose to ethanol. Simultaneous single step bioconversion from unhydrolyzed sago starch into ethanol will not only reduce the cost of enzymes that is used in liquefaction and saccharification steps but will also reduce the substrate inhibition, especially on yeast cells. Besides the advantage of using cheaply and readily ragi tapai for conversion of starch to glucose, the feed stock is also cheaper than other starches like corn and potato. The present study had highlighted the importance of well controlled microwave assisted enzymatic reaction to enhance the overall reaction rate of the process. It is worth to point out some general statements: (1) Enzymatic hydrolysis of starch using typical enzymes may successfully be carried out at microwave condition (2) The effect of microwave irradiation strongly depends on: (a) Microwave power level - higher levels of MW may cause denaturation of the enzyme; (b) Viscosity of the reaction system that is the function of starch concentration-in less concentrated slurry the diffusion of heat is uniform with no hot spots and hence allowed the increase the reaction rate without denaturation of the enzyme (3) The dominant factor in the microwave assisted reaction in this study may be treated as non-thermal effects; (4) The Microwave Irradiation-Enzyme Coupling Catalysis (MIECC) effect on ethanol production had shown an reaction rate increase of close to two times.

In the future work, the ethanol produced could be tested on a spark-ignition engine to monitor the emission and other thermodynamic parameters. The ethanol can be tested to see its compliance with ASTM D4806, which is a standard for anhydrous denatured fuel ethanol for blending with gasoline and ASTM D5798, which is a standard specification for fuel ethanol (Ed75-Ed85) for automotive spark-ignition engine.

\section{REFERENCES}

Azmi, A.S., G.C. Ngoh, M. Maizirwan and H. Masitah, 2010. Ragi tapai and Saccharomyces cerevisiae as potential coculture in viscous fermentation medium for ethanol Production. Afr. J. Biotech., 9: 71227127.

http://www.academicjournals.org/AJB/abstracts/ab s2010/180ct/Azmi\%20et\%20al.htm

Bai, F.W., W.A. Anderson and M. Moo-Yong, 2008. Ethanol fermentation technologies from sugar and starch feedstock. Biotechnol. Adv., 26: 89-105. DOI: 10.1016/J.BIOTECHADV.2007.09.002

Balat, M., H. Balat and C. Oz, 2008. Progress in bioethanol processing. Progress Energy Combustion Sci., 34: 551-573. DOI: 10.1016/J.PECS.2007.11.001

Balat, M. and H. Balat, 2009. Recent trends in global production and utilization of bio-ethanol fuel. Applied Energy, 86: 2273-2282. DOI: 10.1016/j.apenergy.2009.03.015

Baras, J., S. Gacesa and D. Pejin, 2002. Ethanol is a strategic raw material. Chem. Indus., 56: 89-104. http://www.doaj.org/doaj?func=abstract\&id=628878

Booske, J.H., R.F. Cooper and S.A. Freeman, 1997. Microwave enhanced reaction kinetics in ceramics. Mater. Res. Innov., 1: 77-84. DOI: $10.1007 / \mathrm{s} 100190050024$ 
Caputi, A.J.R., M. Ueda and J. Brown, 1968. Spectrophotometric determination of ethanol in wine. Am. J. Enol. Viti., 19: 160-165. http://www.ajevonline.org/cgi/content/abstract/19/ $3 / 160$

Chum, H.L. and R.P. Overend, 2001. Biomass and renewable fuels. Fuel Process. Technol., 71: 187195. DOI: 10.1016/S0378-3820(01)00146-1

Gandjar, I., 2003. Tapai from cassava and cereals. Proceedings of the 1st International Symposium and Workshop on Insight into the World of Indigenous Fermented Foods for Technology Development and Food Safety, Aug. 13-17, Kasetsart University, pp: 1-10. http://www.agriqua.doae.go.th/worldfermentedfoo d/I_10_Gandjar.pdf

Goldemberg, J., 2008. Environmental and ecological dimensions of biofuels. http://www.esa.org/biofuels/presentations/Goldem berg_BiofuelsPresentation.pdf

Huang, W., Y.-M. Xia, H. Gao, Y.-J. Fang and Y. Wang et al., 2005. Enzymatic esterification between n-alcohol homologs and n-caprylic acid in non-aqueous medium under microwave irradiation. J. Molecular Catalysis B: Enzymatic, 35: 113-116. DOI: 10.1016/J.MOLCATB.2005.06.004

Jamai, L., K. Ettayebi, J. El Yamani and M. Ettayebi, 2007. Production of ethanol from starch by free and immobilized Candida tropicalis in the presence of a-amylase. Bioresour. Technol., 98: 2765-2770. PMID: 17127052

Khanal, S.K., M. Montalbo, J.H. Van Leeuwen, G. Srinivasan and D. Grewell, 2007. Ultrasound enhanced glucose release from corn in ethanol plants. Biotech. Bioeng., 98: 978-985. PMID: 17514753

Kim, S. and B.E. Dale, 2005. Environmental aspects of ethanol derived from no-tilled corn grain: Nonrenewable energy consumption and greenhouse gas emissions. Biomass Bioenergy, 28: 475-489. DOI: 10.1016/J.BIOMBIOE.2004.11.005

Kuhnert, N., 2002. Microwave-assisted reactions in organic synthesis-are there any nonthermal microwave effects? Angew. Chem. Int. Ed., 41: 1863-1866. 3773(20020603)41:11<1863::AID-

ANIE1863>3.0.CO;2-L

Leadbeater, N.E., L.M. Stencel and E.C. Wood, 2007. Probing the effects of microwave irradiation on enzyme-catalysed organic transformations: The case of lipase-catalysed transesterification reactions. Org. Biomol. Chem., 5: 1052-1055. PMID: 17377658
La Hoz, D., A. Diaz-Ortiz and A. Moreno, 2007. Review on non-thermal effects of microwave irradiation in organic synthesis. J. Microw. Power Electromag. Energy, 41: 44-64. PMID: 18161416

Li, Y.S. and W.S. Yang, 2008. Microwave synthesis of zeolite membranes: A review. J. Membrane Sci., 316: 3-17. DOI: 10.1016/J.MEMSCI.2007.08.054

Miller, G.L., 1959. Use of the dinitroslicylic acid reagent for the determination of reducing sugar. Anal Chem., 31: 426-428. DOI: 10.1021/ac60147a030

Nadir, N., M. Mel, M.I.A. Karim and R.M. Yunus, 2009. Comparison of sweet sorghum and cassava for ethanol production by using Saccharomyces cerevisiae. J. Applied Sci., 9: 3068-3073. DOI: 10.3923/jas.2009.3068.3073

Nikolic, S., L. Mojovic, M. Rakin, D. Pejin and D. Savic, 2008. A microwave-assisted liquefaction as a pretreatment for bioethanol production by the simultaneous saccharification and fermentation of corn meal. Chemical Indus. Chemical Eng. Q., 14: 231-234. DOI: 10.2298/CICEQ0804231N

Nikolic, S., L. Mojovic, M. Rakin, D. Pejin and J. Pejin, 2010. Ultrasound assisted production of bioethanol by simultaneous saccharification and fermentation of corn meal. Food Chem., 122: 216-222. DOI: 10.1016/J.FOODCHEM.2010.02.063

Nurachman, Z., A. Kono, O.K. Radjasa and D. Natalia, 2010. Identification of a novel raw-starchdegrading- $\alpha$-amylase from a tropical marine bacterium. Am. J. Biochem. Biotechnol., 6: 300306. DOI: 10.3844/ajbbsp.2010.300.306

Palav, T. and K. Seetharaman, 2007. Impact of microwave heating on the physico-chemical properties of a starch-water model system. Carbohydr. Polym., 67: 596-604. DOI: 10.1016/J.CARBPOL.2006.07.006

Roy, I. and M. Gupta, 2003. Applications of microwaves in biological sciences. Curr. Sci., 85: 1685-1693.

http://cat.inist.fr/?aModele $=$ afficheN\&cpsidt $=1539$ 5941

Saifuddin, N., A.Z. Raziah and H.N. Farah, 2009. Production of biodiesel from high acid value waste cooking oil using an optimized lipase enzyme/acidcatalyzed hybrid process. E-J. Chem., 6: S485S495. http://www.e-journals.in/PDF/V6NS1/S485S495.pdf

Saifuddin, N., L.W. Zhan and K.K.X. Ning, 2011. Heat-modeling of microwave assisted epoxidation of palm acid oil. Am. J. Applied Sci., 8: 217-229. DOI: 10.3844/ajassp.2011.217.229 
Semin, R., A. Bakar and A.R. Ismail, 2009. Green engines development using compressed natural gas as an alternative fuel: A review. Am. J. Environ. Sc., 5: 371-381. DOI: 10.3844/ajessp.2009.371.381

Srikanta, S., S.A. Jaleel, N.P. Ghildyal and B.K. Lonsane, 1992. Techno-economic feasibility of ethanol production from fresh cassava tubers in comparison to dry cassava chips. Food, 36: 253258. DOI: $10.1002 /$ food. 19920360306

Somda, M.K., A. Savadogo, C.A.T. Ouattara, A.S. Ouattara and A.S. Traore, 2011. Improvement of bioethanol production using amylasic properties from Bacillus licheniformis and yeasts strains fermentation for biomass valorization. Asian J. Biotechnol., $\quad 3$ : 254-261. http://docsdrive.com/pdfs/knowledgia/ajbkr/0000/2 1566-21566.pdf

Wang, D., S. Bean, J. McLaren, P. Seib and R. Madl et al., 2008. Grain sorghum is a viable feedstock for ethanol production. J. Ind. Microbiol. Biotechnol., 35: 313-320. DOI: 10.1007/s10295-008-0313-1
Yadav, G.D. and P. Lathi, 2007. Microwave assisted enzyme catalysis for synthesis of n- butyl dipheyl methyl mercapto acetate in non-aqueous media. Clean Technol. Environ. Policy, 9: 281-287. DOI: 10.1007/s10098-006-0082-3

Yadav, G.D. and A.D. Sajgure, 2007. Synergism of microwave irradiation and enzyme catalysis in synthesis of isoniazid. J. Chem. Technol. Biotechnol., 82: 964-970. DOI: 10.1002/jctb.1738

Zhu, S., Y. Wu, Z. Yu, C. Wang and F. Yu et al., 2006. Comparison of three microvawe/chemical pretreatment processes for enzymatic hydrolysis of rice straw. Biosyst. Eng., 93: 279-283. DOI: 10.1016/J.BIOSYSTEMSENG.2005.11.013 